Ministry of Technology, where Professor Blackett deputizes for the minister as chairman of the principal advisory committee. His starting point was the recognition that "the present crisis" is also an opportunity to put the relationship between industry and technology in order. In passing, he took care to insist that the margin between crisis and solvency is a mere $£ 500$ million a year in exports-a kind of Micawber pittance.

But why do exports lag behind ? Because productivity is low, which is in turn a consequence of too little capital investment. Only 15 per cent of the GNP in Britain is being spent on new "productive machinery", compared with 21 per cent in West Germany. But Britain has also failed to provide industrial management with enough technical skill. "The professional world as a whole must take a big share of the twin errors of underestimating both the needs of Britain for technologically trained manpower in general and for a new breed of technologically trained managers in particular'. So, Professor Blackett argued, Britain must train a greater proportion of its people in scientific skills, and plans based on the Robbins report must be "rapidly implemented and in no way whittled down".

Professor Blackett went on to argue that even though Britain stood well in international comparisons of the proportion of the national income spent on research and development, the great proportion spent on defence research "which is usually unproductive of growth" means that the figures are somewhat misleading. In fact, Britain carries out roughly 5 per cent of all the research and development in the world and must therefore live by the slogan-attributed to Mr. Leon Bagrit-that one should "never re-invent". The problem is to decide how to "concentrate the country's technological effort and not to waste it by spreading it too thin in too many fields". Professor Blackett thought it would be disastrous if Britain limited its production methods to the means of production it had itself invented-- "though it is very important to make electronic computers, it is still more important to use them". For all these reasons, he thought that a country like Britain, constantly aware of problems of balancing external payments, must make what use may seem necessary of foreign development, skill and technique.

On the relationship between research and development and the economic viability of individual companies, Professor Blackett pointed out that the cost of developing a new product, measured either in money or in skilled man years, is likely to be a constant determined by the product itself. But few companies can afford to spend more than 10 per cent of their turnover on research and development, so that to recover the cost of a research and development programme implies that sales of the products concerned must amount to something like ten times the development cost. In other words, "rather simple arithmetic relations exist between the fundamental and numerical parameters relating to any firm". Moreover, the minimum size of a viable company "able to do its own research and development is inversely proportional to the output from employees". Because the average output of an employee in Britain is rather less than in the United States, it follows that the minimum size of a company in Britain may often be less than that of viable companies elsewhere. Given this kind of thinking, it is easy to see where the Ministry of Technology's enthusiasm for mergers has sprung from. In his Fawley lecture, Professor Blackett added the reservation that he was not talking of "mammoth firms" and also suggested that "the optimum size would be perhaps near the minimum required to satisfy" the conditions he had specified.

\section{Less School Science}

There is a mixture of good and bad news in the information collected from schools in Britain in January 1966, and which has now been processed by computer at the Department of Education and Science. Despite the growth in the number of children in the schools caused by the rising birth rate in the fifties, the average number of pupils per teacher has shown a slight improvement, from $23 \cdot 5$ to $23 \cdot 2$. The improvement is concentrated in the secondary schools, however, and the primary schools show no improvement at all, with a ratio which is constant at 32.6 pupils per teacher. The tendency for pupils to stay at school after they reach the statutory leaving age is increasing, but the South of England and Wales are still far ahead in this respect, and the rest of the country shows no sign of catching up. This tendency is shown by the number of pupils reaching the sixth forms, which has risen by 42 per cent in four years.

A depressing feature of this rise is that it shows a swing away from the scientific and mathematical subjects. Since 1965 the number studying these subjects in the sixth forms of grammar schools has declined by more than 4.5 per cent, while the number studying exclusively arts subjects has increased by $1 \cdot 3$ per cent. What seems to be happening is that pupils are increasingly tending to study one science subject and at least one other; although still small numerically, this category has increased by 7.5 per cent over the year, and by 100 per cent since 1962 .

\section{Engineers as Heroes}

"The Engineers' Day", an exhibition organized by the Ministry of Technology, opened at the Science Museum in London last week. Alarmed by the shortage of engineers, nationalized industries, government departments, the armed forces and the engineering institutions have conspired with the ministry to organize the exhibition, which is directed at schoolchildren. The theme is a day in the life of a professional engineer, and many examples of the engineer's work are shown. There are even some engineers on hand to describe to the children the work they do. Organized parties from schools will be given preference over casual visitors, and so far 20,000 children have booked to see the exhibition, which will run until January 14.

As far as it goes, the exhibition should be a success. It is colourful and well arranged, and should give the Museum cause for shame over its own rather depressing children's section. The exhibition twists and turns like the maze at Hampton Court, and through portholes in the wall glimpses of the permanent exhibits at the Museum can be seen. Many of these are examples of the work of the great Victorian engineers, who knew what it was like to be glorified. There are, however, two lapses. First, no attempt is made to define the engineer's career structure. 'The impression is given that, once qualified, the engineer spends the rest of 